\title{
A Crisis in Leadership: Transforming Opportunistic Leaders into Leaders that can be Trusted
}

\section{Desmond W. $\mathrm{Ng}^{1}$ (D) $\cdot$ Wyoma vanDuinkerken ${ }^{1}$}

Accepted: 24 October 2020 / Published online: 9 January 2021

(C) The Author(s) 2020

\begin{abstract}
Business leaders often rely on the power of their authority to influence their employees. Recent workplace surveys however have found a growing distrust in a business leader's authority. While such distrust has been increasingly associated with abuses in a leader's authority, leadership research has primarily focused on the positive outcomes of leadership. The task of this study is to develop a conceptual model of leadership to address this shortcoming. In drawing Transaction Cost Economics (TCE), a concept of opportunistic authority was developed to explain employees' distrust in their leader's authority. This opportunistic authority is defined by a legal and moral opportunism in which a leader in a position of authority seeks to beguile, cloak and / or deceive employees of their legal and moral responsibilities. Legitimacy is identified as a solution to overcoming this opportunistic authority. Specifically, a leader's efforts to develop pragmatic and moral forms of legitimacy develop normative expectations in upholding a leader's legal and moral responsibilities. These normative expectations reduce a leader's legal and moral opportunism and develop employees' trust in the leader's authority. A contribution of this study is that it not only offers a "darker side" explanation of leadership, but it also introduces a legitimizing process that can transform "ass**le" leaders into leaders that can be trusted.
\end{abstract}

Keywords Leadership $\cdot$ Authority $\cdot$ Legitimacy $\cdot$ Organizational economics $\cdot$ Ethics

I believe there are more instances of the abridgment of the freedom of the people by gradual and silent encroachments of those in power than by violent and sudden usurpations.

-James Madison

Desmond W. Ng

dng@tamu.edu

Wyoma vanDuinkerken

wvanduin@tamu.edu

1 Texas A\&M University, College Station, Texas 77845, USA 


\section{Introduction}

Leadership is in a state of crisis. There is an increasing recognition that leaders are abusing their positions of authority (Bendahan et al. 2015; Liu et al. 2012; Lubit 2002; Vrendenburgh and Brender 1998; Wee et al. 2017). Such abuses range from personal insults, threats of intimidation and termination, uninvited physical contact, public humiliation, and advancement of personal agendas (Conger 1990; Lubit 2002; Sutton 2007). Empirical studies have found that such abuses have cost United States organizations $\$ 24$ billion a year in lost productivity, staff turnover, legal fees and damaged corporate reputations (Wee et al. 2017). This "darker" view of leadership stands in contrast to the lighter or more positive explanations of leadership (Alvesson and Spicer 2012; Conger 1990; Liu et al. 2012; Spoelstra et al. 2016). According to the positive view, leadership is equated to a position of authority because authority provides leaders the power to motivate employees in achieving a common vision (Ashford and Sitkin 2019; Choudhary et al. 2013). While such a position of authority is important to realizing an organization's goals and vision, the reality is that employees cannot be expected to obediently trust and follow their leaders (Ashford and Sitkin 2019; Dishman 2016). A recent IPSO Reid survey finds that only $22 \%$ of employees trust their business leaders and $32 \%$ outright distrust them (Featherston 2019). Other work place surveys found that employees' trust declines with their position in the organizational hierarchy where " $64 \%$ of executives, $51 \%$ of managers, and $48 \%$ of rank and file staff say they trust their organizations, and employees say they trust peers more than CEOs when it comes to company information" (Comaford 2017). Positive explanations of leadership face difficulties explaining this lack of trust because it implicitly assumes that leaders are a morally objective or neutral party. ${ }^{1}$ This study challenges this morally neutral position in which a leader's authority can be a source of opportunism that advances a leader's interests at the expense of their employees. The task of this study is to introduce concepts of "legitimacy" to overcome the opportunism in a leader's authority.

To elaborate, while exchanges between organizational economics and leadership have been generally rare (Zehnder et al. 2017), Williamson's (1993) Transaction Cost Economics (TCE) has warned us that authority creates opportunities for leaders to abuse their position of influence (Conger 1990; Vrendenburgh and Brender 1998). Williamson (1993) describes this opportunism where “...leadership will inevitable develop attachment to the office...[and]...the entrenched leader will use the organization to promote its own agenda at the expense of the membership" (p. 117). For instance, Dr. Edwin Price, the inventor of the Polaroid camera, had a personal ambition to develop a replacement instant camera that far exceeded the technical needs of the average customer. This personal ambition resulted in significant financial losses to the company and to its employees (Conger 1990). Such abuses in authority can also create opportunities for leaders to engage in highly despotic or tyrannical behaviors. In Sutton's (2007) provocatively titled book, "the No Asshole rule...", he cites an example in

\footnotetext{
1 Mainstream treatments of Transaction Cost Economics also share a similar morally neutral assumption (Ghoshal and Moran 1996; Moschandreas 1997).
} 
which a Hollywood executive fired 250 personal assistants because they brought him the wrong muffin. According to Sutton (2007), this executive was a certified "asshole" because he abused his position of authority to bully and intimidate his subordinates (see also Lubit 2002). A growing number of empirical studies on "dark / destructive" leadership has confirmed these and other types of abuses in a leader's authority and found that such abuses can result in significant declines in an employee's trust (Bendahan et al. 2015; Lubit 2002; Wee et al. 2017). Hence, the challenge or research problem facing leadership research is: how can a leader develop trust in their employees, when a leader's authority is subject to an opportunism that can abuse their trust? In more pejorative terms, how can employees develop trust in their leadership when they act like "assholes"? (see also Pfeffer 2016).

As there has been recent calls to integrate the insights of TCE into leadership research (Zehnder et al. 2017), the objective of this study is to develop a "dark side" explanation of the TCE's concept of authority (Coase 1937; Williamson 1975). A concept of opportunistic authority is developed in which unlike TCE, a leader's authority involves more than just a superior-subordinate relationship. This is because a leader's authority operates within a greater institutional setting in which leaders face normative expectations to uphold the legal and moral responsibilities of their authority (see also Lea 2004; Long and Driscoll 2008; Ng 2019; Tucker and Hendrickson 2004; Warren 2003). Opportunistic authority arises when leaders in positions of authority fail to live to the legal and moral responsibilities of their position. A core contribution of this study is that this concept of opportunistic authority not only offers a "dark side" explanation to TCE's concept of authority, but it also introduces an institutional process that transforms dark leaders into leaders that can be trusted. Specifically, while TCE analysis does not deal with the institutional processes surrounding the abuses in a leader's authority, Williamson (1993) recognizes that institutions can promote a normative expectation of trust that constraints an individual's opportunism (see also Monk 2009; Chiles and McMackin 1996). This is because institutions consist of a legitimizing process in which conformance to normative expectations reduces the probability that parties to an exchange will take advantage of the other (Chiles and McMackin 1996; Williamson 1993). This legitimizing process is explained by "pragmatic and moral" forms of legitimacy (Suchman 1995) in which the development of "procedural justice" and "servanthood" develops a normative expectation that leaders can be trusted to uphold the legal and moral responsibilities of their position. As a result, a contribution of this study is that pragmatic and moral forms of legitimacy not only introduce an institutional process that is absent in TCE research, but this legitimizing process offers a solution to a leader's opportunistic authority.

\section{Conceptual development}

\subsection{Definitions, unit of analysis and boundary condition}

In order to develop this study's conceptual model, its definitions, units of analysis and boundary conditions are first outlined. In defining this study's concept of 
authority, leadership studies define authority in terms of a power asymmetry (Alvesson and Spicer 2012; Bendahan et al. 2015; Choudhary et al. 2013; Wee et al. 2017). This power-asymmetry involves a dependence in which employees' wellbeing is dependent upon the power and influence of their leaders (Wee et al. 2017). While this authority is implicit to most forms of leadership (Ashford and Sitkin 2019; Bendahan et al. 2015; Choudhary et al. 2013; Smith et al. 2004; Wee et al. 2017), an examination of the governance structures surrounding this authority remains limited (see Ashford and Sitkin 2019; Eva et al. 2019; Zehnder et al. 2017). This is because leadership research focuses on a leader's personality traits in gaining the cooperation of their employees but fails to recognize that a leader's influence also stems from their authority (Zehnder et al. 2017). Zehnder et al. (2017) argued that TCE offers a unique contribution to leadership research because TCE attributes a leader's influence and power to the governance properties of their authority.

To explain this governance, TCE has defined authority by a super-subordinate relationship (Coase 1937). The leader in this super-subordinate relationship consists of individuals, such as the CEO or the entrepreneurial founder of an organization (Coase 1937). This study focusses on the leadership of senior members and not supervisory managers because the actions of senior leaders are subject to greater public scrutiny and thus face stronger pressures to conform to the normative expectations of society (see also Long and Driscoll 2008). In addition, this study also focusses on organizations that exhibit a strong hierarchical or bureaucratic structure (Vrendenburgh and Brender 1998; Zehnder et al. 2017). According to dark side explanations of leadership, leaders in these hierarchical organizations are subject to fewer external controls and thus are more likely to abuse their positional authority (e.g. Bendahan et al. 2015; Liu et al. 2012; Peterson et al. 2012; Wee et al. 2017). In defining this study's boundary conditions, leadership studies find that these hierarchically organized businesses are subject to social learning processes in which a leader's abusive behaviors have a "cascading effect" that impacts the lowest level employees of their decision hierarchy (Liu et al. 2012). Due to such "cascading effects", this study's boundary condition is focused on the abusive exchanges found between the senior leader and their front-line employees (see also Bendahan et al. 2015).

\subsection{Opportunistic authority: leadership and transaction cost economics (TCE) treatments of authority}

While leadership and authority have developed on largely separate lines, TCE's concept of authority is important to informing both the darker and lighter sides of leadership (see also Ghoshal and Moran 1996; Moschandreas 1997; Zehnder et al. 2017). From the standpoint of the lighter or more positive aspects of leadership, leaders are delegated a position of authority because this positional authority offers governance benefits that reduce the transaction costs of market exchange. Specifically, market exchanges consist of legal as well as moral contractual exchanges (Williamson 1993) that are "necessarily incomplete" (Williamson 1975). Due to bounded rationality, leaders cannot fully specify all the contingencies surrounding 
a market-based contract. As a result, leaders incur transaction costs in writing, negotiating and enforcing the contingencies of these market-based exchanges in which these transaction costs mitigate opportunities for an exchange partner to take advantage of contingencies not specified in the contract. Coase (1937) argued that by reducing transaction costs, organizations replace these market-based exchanges with an organization's authority. This authority involves placing the leader or entrepreneur into a super-subordinate relationship with their employees. Under this authority, a leader does not need to need to fully specify the contingencies of a market-based contract because employees will be simply directed to address the contingencies as they arise. This authority thereby reduces the transaction costs of market exchange because it replaces many contingent market-based contracts with a single employment contract (Coase 1937). While TCE's concept of authority offers governance benefits that reduces the transaction costs of market exchange, Williamson (1993) and others (Ghoshal and Moran 1996; Moschandreas 1997) have also warned of the darker side of this authority. They argued that authority can create opportunities for leaders to abuse their position. Yet, mainstream TCE research-as well as leadership research (Alvesson and Spicer 2012; Zehnder et al. 2017)-have largely ignored these warnings because they assume that leaders are morally neutral (Ghoshal and Moran 1996; Moschandreas 1997). This morally neutral assumption finds that opportunism applies mostly to employees and not to leadership and thus leadership abuses of authority have been generally ignored by mainstream TCE research (Ghoshal and Moran 1996; Moschandreas 1997). This morally neutral assumption is however challenged by a growing body of dark side leadership research (Alvesson and Spicer 2012) that finds power asymmetries in a leader's authority (Williamson 1993) can create opportunities to abuse their position of influence (Bendahan et al. 2015; Lubit 2002; Peterson et al. 2012; Schyns and Schilling 2013; Schuh et al. 2013; Wee et al. 2017). A concept of opportunistic authority is thus developed to address these leadership abuses in TCE research. Two normative assumptions are first outlined.

First, while leaders may aspire to do what is right (Eva et al. 2019), a position of authority introduces opportunities for a leader to leverage their position of influence for their personal gain (Bendahan et al. 2015; Chatterjee and Hambrick 2007; Conger 1990; Lubit 2002; Schuh et al. 2013). This is not to imply that all leaders will engage in such opportunism; only that authority has a seductive influence that can compromise a leader's moral standing (Bendahan et al. 2015). Bendahan et al. (2015) describes this seductive influence where he noted that when moral leaders ascend to positions of authority, their moral position change "... rather easily once they got a taste of power." (p. 119). This corruptive influence of authority speaks to the frailty of an individual's morality (Williamson 1993). It reflects a man's deep spiritual struggle that we all aspire to do what is right, but often fail to live up to our moral standards. As the apostle Paul had once noted, "for I do not do the good I want to do. Instead, I keep on doing the evil I do not want to do" (New International Version (NIV): Romans 7:19). As a result, this study's normative position on authority is that it is a morally neutral concept, but when considering the frailty of man's moral condition, authority provides a power-asymmetry that reinforces his/ her fallen nature. 
A second normative assumption is that a leader's abuse of their authority implies that a leader has failed to live up to the responsibilities expected of their authority. A position of authority comes with normative expectations that leaders are to fulfill certain legal and moral responsibilities to their employees (e.g. Barnard 1938; Lea 2004; Long and Driscoll 2008; Ng 2019; Warren 2003). These normative expectations involve a social contract in which "business behavior is brought into conformance to society's expectations" (Long and Driscoll 2008; p. 175; see also Warren 2003). This social contract involves a norm or code of ethics in which business leaders are legally and morally responsible to its constituent members (Long and Driscoll 2008; Warren 2003). For instance, society places demands on business leaders to be held legally responsible for making a payment of wages to their employees (Ng 2019; Phillips 2003). A leader who fails to uphold this legal responsibility will call into serious question their legitimacy as a legal corporate entity (Long and Driscoll 2008). In addition, since leaders have the power to significantly influence the lives of their employees, society increasingly holds business leaders morally responsible to the well-being of their employees (i.e. \$15 dollar wage; commitments to employees' life-long learning) (Lea 2004; Long and Driscoll 2008; Ng 2019; Warren 2003). As result, unlike the superior-subordinate relationship of TCE, a leader's authority operates within a greater institutional setting in which this superior-subordinate relationship consists of a normative expectation to uphold the legal and moral responsibilities of their authority.

In drawing on this study's two normative assumptions, a concept of opportunistic authority is developed. This concept of opportunistic authority introduces an institutional argument to TCE explanations. In particular, while Williamson (1993) recognizes the importance of institutions to TCE analysis, TCE is focused only on the governance aspects of authority. Thus, the institutional norms or normative expectations surrounding a leader's authority has been generally neglected (Williamson 1993). In response to this institutional shortcoming, leaders in a position of authority face pressures to align their conduct with society's normative expectations (Long and Driscoll 2008; Warren 2003). This alignment introduces a legitimacy to a leader's authority in which employees can trust that their leaders will uphold the legal and moral responsibilities of their social contract (Long and Driscoll 2008; Lee et al. 2018; Tucker and Hendrickson 2004). However, since positions of authority have a corruptive influence on leaders, leaders face opportunities to violate these normative expectations and thus will fail to live up to the legal and moral responsibilities of their authority. Opportunistic authority thus deals with this corruptive aspect of a leader's authority. More formally, opportunistic authority is defined by a legal and moral opportunism in which a leader in a position of authority seeks to beguile, cloak and / or deceive employees of their legal and moral responsibilities.

\subsubsection{Legal opportunism}

To elaborate on the components of this opportunistic authority, legal opportunism involves exploiting a leader's position of authority to cheat, lie and or obfuscate employees' legal claims. Such legal opportunism can be observed in recent debates surrounding the hiring practices of Disney. In an effort to reduce labor costs, critics 
have alleged Disney for recruiting foreign workers to displace their current IT workers. The use of foreign workers can significantly lower Disney's legal obligations to their current workers because highly trained foreign workers-under the H1B program- can be paid a much lower labor rate than the displaced domestic workers (Wisner 2016). Other forms of legal opportunism can arise in which senior managers misreport their employee's productive contributions (Conger 1990; Harvey et al. 2007; Lubit 2002; Wee et al. 2017). According to the popular business press (Shellenbarger 2019), employees, especially at junior ranks, have documented that their marketing and business ideas are often taken without credit by their senior managers. Senior managers justify this legal opportunism on grounds of their authority by saying "you [employees] work for me, and [thus] anything you do-I own it. And if you don't like it, there's the door." (Shellenbarger 2019).

\subsubsection{Moral opportunism}

In addition to such legal opportunism, moral opportunism involves efforts by leaders to use their authority to beguile or deceive employees of a leader's moral responsibilities. According to leadership studies, a leader has a moral responsibility to empower their employees (e.g. Argyris 1998; Barnard 1938; Eva et al. 2019; Lee and Koh 2001; Liden et al. 2014). Empowerment is a recognition of an employees' intrinsic worth where leaders have a moral responsibility to fully realize their employees' productive potential, self-actualization needs and goals (Argyris 1998; Eva et al. 2019; Lee et al. 2018; Lee and Koh 2001). For instance, leaders can empower employees by encouraging employees to take on greater personal responsibilities, to define work objectives and targets, and to develop and explore their personal talents and skills (Eva et al. 2019). Yet, in spite of this moral responsibility, leaders may lack a genuine commitment to empowering their employees (Argyris 1998). This is because as empowerment increases an employee's self-determination, employees are not subject to a leader's authority and thus reduces a leader's power and influence (Argyris 1998; Lee and Koh 2001). In order to maintain a leader's authority, moral opportunism involves efforts to mislead employees into believing that the leader is sincere in their commitments to empowering their employees. This moral opportunism involves promoting the virtues of empowerment by allowing employees to do their own thing, but at the same time, employees must ultimately obey the leader's authority. This type of moral opportunism is described by Argyris (1998) where he notes, leaders proclaim the virtues of employee empowerment so long as it is done their way; that is "do your own thing in the way I tell you!" (p. 102). This moral opportunism is opportunistic in nature because leaders seek to give an appearance of a "genuine" commitment to empowering their employees' welfare, where in fact this commitment seeks to reinforce a leader's dominant position.

\subsection{TCE's treatment of trust and legitimacy}

To overcome such legal and moral opportunism, institutional explanations argue that trust offers a normative expectation that constraints an individual's opportunism 
(Monk 2009; see also Chiles and McMackin 1996; Williamson 1993). Trust is a "belief that an institution is performing in accordance with their normative expectations" (Monk 2009, p. 458). This normative expectation of trust has been described by a subjective probability (see also Chiles and McMackin 1996) in which Gambetta (1988) defines:

trust... is a particular level of the subjective probability with which an agent assesses that another agent or group of agents will perform a particular action.... When we say we trust someone or that someone is trustworthy, we implicitly mean that the probability that he will perform an action that is beneficial or at least not detrimental to us is high enough for us to consider engaging in some form of cooperation with him. (p. 217).

By drawing on this distinction, trust involves a normative expectation that parties assign a high probability that each will not take advantage of the other. Such trust is implicit to legal and moral exchanges (Chiles and McMackin 1996; Williamson 1993). For instance, legal exchanges carry a certain degree of trust because if parties, such as employees, seek to specify all the contingencies of their employment contract, it indicates their lack of trust in their leader (Chiles and McMackin 1996). In addition, since moral obligations are legally unenforceable (Lea 2004; Ng 2019), moral exchanges carry a trust in which employees assign a high probability that their leaders have a personal duty to honoring their moral commitments (Chiles and McMackin 1996).

\subsection{Legitimate authority}

As trust involves the development of normative expectations (Chiles and McMackin 1996; Williamson 1993), a concept of legitimacy has been used to explain the development of these normative expectations in a leader's authority (see also Long and Driscoll 2008; Schwarz et al. 2016; Tucker and Hendrickson 2004; Warren 2003). Legitimacy is a property of social exchanges where parties face a social obligation to conform to the normative expectations of another (Suchman 1995). More specifically, legitimacy refers to.

"a generalized perception or assumption that the actions of an entity are desirable, proper, or appropriate within some socially constructed system of norms, values, beliefs and definitions... [where] ...Legitimacy is a perception or assumption in that it represents a reaction of observers to the organization as they see it" (Suchman 1995; p. 574).

In the context of this study, legitimacy is defined by an employee's normative expectation that leaders will live up to the legal and moral responsibilities of their authority (see also Long and Driscoll 2008; Tucker and Hendrickson 2004; Warren 2003). By drawing on this notion of legitimacy, a basic task of leadership is to institute a legitimacy in their authority in which a normative expectation of trust is developed with their employees (see also De Fine Licht et al. 2014). The development of this trust in a leader's authority is explained by pragmatic and moral forms 
of legitimacy (see also Dart 2004; Palazzo and Scherer 2006; Suchman 1995). This study argues that pragmatic and moral legitimacy are important to developing an employee's trust in their leader's authority and thus offer a solution to resolving a leader's opportunistic authority. Each of these forms of legitimacy are explained as follows:

\subsection{Pragmatic legitimacy}

Pragmatic legitimacy is defined by "a sort of exchange legitimacy-support for an organizational policy based on that policy's expected value to a particular set of constituents" (Suchman 1995, p. 578). Employees ascribe pragmatic legitimacy to a leader when the leader offers significant and tangible benefits to the employee (Suchman 1995). Such pragmatic legitimacy typically involves a material exchange wherein exchange of financial rewards, such as a timely payment of wages, awarding of bonuses, stock options, health/dental care benefits etc., the leader gains the practical support or legitimacy from its employees. By gaining the support of their employees, pragmatic legitimacy offers an obedience to a leader's decision-making authority. While the use of such material exchanges is important to gaining employees' pragmatic legitimacy Suchman (1995), argues that employees are more willing to accept the decisions of a leader's authority when employees have a stake in their leader's decision-making process. This form of pragmatic legitimacy has been defined as an "influence" legitimacy where:

"constituents support the organization not necessarily because they believe that it provides specific favorable exchanges, but rather because they see it as being responsive to their larger interest. Most often, influence legitimacy arises when the organization incorporates constituents into its policy-making structure or adopts constituent's standards of performance as its own" (Suchman 1995, p. 578).

\subsubsection{Procedural justice}

This pragmatic (influence) legitimacy has been described by a "procedural justice" (Greenwood 2007; Harrison et al., 2010; Phillips 2003). Procedural justice refers to an ethical view of fairness (Rawls 1971) in which individuals perceive that outcomes are fair, if they have a say in determining the processes used in generating these outcomes (Harrison et al. 2010; Phillips 2003). With this procedural justice, employees who are engaged in a leader's decision-making process will develop a greater perception of fairness in a leader's decision-making (Greenwood 2007; Phillips 2003). This suggest that a leader who develops an authority based on a procedural justice is more likely to gain the support and pragmatic (influence) legitimacy of their employees. This is because employees are more willing to accept decisions when they have an input to a leader's decision-making authority.

To develop this procedural justice, leaders are called to develop a greater transparency in their decision-making (Bendahan et al. 2015; De Fine Licht et al. 2014; Ferejohn 1999). Studies argue that an open reporting of a decision-maker's actions 
is positively related to a decision maker's legitimacy (De Fine Licht et al. 2014). This transparency opens a decision maker's actions to public scrutiny. In exchange for this greater scrutiny, the decision maker is granted a greater investment of power and legitimacy by their constituents (De Fine Licht et al. 2014; Ferejohn 1999). From the standpoint of developing a leader's pragmatic (influence) legitimacy, this transparency involves an open reporting of their employees' productive contributions as well as a transparent reporting of the criteria used in evaluating their performance. This transparency develops a legitimacy that their leader's decision-making authority is based on a procedural justice in which employees can openly assess and dispute their leader's assessment of their productive contributions. Leaders subsequently gain the support of their employees, because employees are more willing to accept a leader's authority when employees have a stake in their leader's evaluations of their performance.

A consequence of this pragmatic (influence) legitimacy is that it reduces a leader's legal opportunism. Pragmatic (influence) legitimacy creates a normative expectation that the leader is committed to a transparent reporting of their employees' productive contributions. This normative expectation of transparency enables employees to hold their leaders legally accountable to which increases employees' ability to assert their legal claims to the business ( $\mathrm{Ng} 2019)$. This transparency is consistent with leadership studies where Lubit (2002) argued that a policy of transparency offers an important means of protecting an employee's productive contributions. This study however argues that transparency is not only attributed to a leader's pragmatic (influence) legitimacy, but that this legitimacy also reduces a leader's legal opportunism. For instance, a leader can use their position of authority to take credit for their employee's productive contributions and /or blame their mishaps on their employees (Harvey et al. 2007; Lubit 2002). Employees cannot dispute such leadership abuses because the leader can retaliate the employee with poor annual evaluations, a denial of a promotion, and / or relocate the employee to poor performing business units (Lubit, 2002). Pragmatic (influence) legitimacy circumvents such leadership abuses because it produces a normative expectation of transparency that restricts the leader from using their authority to misreport and distort their employees' productive contributions. This is consistent with developments in leadership research where Bendahan et al. (2015) find the development of normative expectations can limit a leader's discretional choices to which reduces the corruptive influences of authority.

Parallel to such arguments, a leader's pragmatic (influence) legitimacy develops employees' trust in their leader's authority. Pragmatic (influence) legitimacy develops a trust in which employees ascribe a high probability that the leader will honor their legal responsibilities in a fair and open manner. This high probability stems from a leader's pragmatic (influence) legitimacy. A leader's pragmatic (influence) legitimacy develops a normative expectation that employees' productive contributions will not be evaluated on the basis of a leader's personal bias or self-interest. But rather, on the basis that the leader will evaluate their employees' productive contributions in a fair and open manner. This fairness and openness develop a trust in which employees assign a high probability that the leader will honor their legal responsibility. This is because transparency promotes a normative expectation where 
a commitment to fairness and openness not only reduces a leader's legal opportunism, but with this reduction of legal opportunism, employees develop a trust that their leaders will openly and fairly honor their legal claims. In that, a leader who seeks to take advantage of their employees' vulnerabilities will undermine their employees' trust to which reduces a leader's authority to legitimately govern these employees. Hence, a leader's pragmatic (influence) legitimacy produces a normative expectation of transparency in which the leader will not engage in a legal opportunism that will take advantage of their employees' vulnerabilities and thus increases employees' trust in the leader's authority. This legitimacy argument is consistent with leadership studies that find procedural justice promotes a fair and open environment that increases employees' trust in their leaders (De Fine Licht et al. 2014; Parris and Peachey 2013).

\subsubsection{Pragmatic legitimacy and TCE analysis}

As Williamson (1993) has made calls to integrate institutional insights into TCE analysis, pragmatic legitimacy introduces an ethics of fairness in legal exchanges. In TCE, a leader's legal exchanges with their employees are structured around a distributive justice in which employees are compensated in proportion to their productivity (Ng 2019; Phillips 2003). Yet, because TCE ignores the normative expectations of a leader's authority, the governance of such legal contracts does not factor in society's demands for a fairness in legal exchanges (e.g. Taylor et al. 1995). A leader's efforts to develop a procedural justice in their authority is a response to addressing such demands (Taylor et al. 1995). In that, procedural justice creates a normative expectation of transparency in which leaders not only owe an obligation to evaluate their employees in a fair and open manner, but that employees are owed a right to a "due process" in which employees can dispute and/or provide inputs in their evaluation process (Taylor et al. 1995). This obligation is consistent with (Rawl's 1971) ethical view of justice in which the establishing of a procedural justice in social contracts is important to instituting a fairness in social exchange (see also Gustafsson 2004). ${ }^{2}$ In particular, since this procedural justice is rooted in a leader's pragmatic legitimacy, pragmatic legitimacy is central to developing this Rawlsian (Rawl's 1971) view of justice. With this legitimacy, leaders seek a procedural justice to gain the support of their employees and in return for their support, a leader's authority is subject to a normative expectation of transparency. Hence, unlike TCE, this normative expectation of transparency introduces an ethics of fairness into a leader's authority in which an obligation of fairness is owed to the legal exchanges with their employees.

\footnotetext{
${ }^{2}$ While Rawls (1971) defines other types of procedural justice, such as imperfect and pure forms of procedural justice, the more commonly cited example of perfect procedural justice is defined by an exchange when "there is an independent standard for deciding which outcome is just and a procedure guaranteed to lead to it." This perfect procedural justice is illustrated by Rawls (1971) "cake cutting example". A fair outcome arises by allowing one individual to cut the cake and lets others choose before him. Rawls (1971) argues that this "independent standard" yields a fair outcome because the individual will divide the cake equally to ensure that he will attain the largest share possible. For criticism of this procedural justice, see Gustfasson (2004).
} 
This fairness not only develops a trust that governs a leader's legal opportunism, but as result also introduces a trust to TCE analysis.

It is important to recognize that while procedural justice introduces a greater transparency to legal exchanges, Roberts (2009) argues that there is a dark side to this transparency. This is because since procedural justice is motivated by a leader's pragmatic legitimacy, a leader's transparency can be driven by efforts to advance their personal self-interests (Roberts 2009). For instance, procedural justice is implicit in some university committees, such as promotion and tenure committees. In these committees, a commitment to openness and fairness is important to legitimizing the promotion and tenure process. This openness and fairness involve being transparent in the criteria used to evaluate a faculty's research productivity (i.e. A journal lists, research grants, student evaluations relative to department means, service commitments, external reviewer of peer institutions etc.) and to provide faculty the right to introduce criteria that is relevant to assessing their research program. The challenge however is that administrative leaders possess strong power and information symmetries that can reduce such faculty governance to a ceremonial or box-ticking exercise. For instance, promotion and tenure committees serve largely as an advisory committee to administrative leaders (i.e. department heads, deans, provosts, chancellor etc.) and thus do not have final decision-making authority on a faculty's promotion and tenure decision. Thus, while most administrative leaders follow the recommendations of their committees (Roberts 2009), opportunistic leaders can ignore these criteria when evaluating those faculty that have been critical of their leadership and / or promote and hire faculty (i.e. pet faculty) that advance the leader's goals. Hence, opportunistic administrators can engage in a transparency on purely pragmatic grounds to advance their self-interest, while at the same time, offer the impression to committees that their input matters. More broadly speaking, this suggests that even though transparent forms of procedural justice are based on a Rawlsian ethics of fairness, a leader's efforts to introduce fairness to social exchanges cannot be separated from a leader's self-interest. This suggests that a leader's commitments to a normative expectation of transparency must also be met with an accountability. With this accountability, a leader must be willing to not only involve faculty/employees in the decision-making process, but they must also be willing to implement their faculty/ employee's input and decisions. In the absence of this accountability, a leader's procedural justice will lack a "genuineness" in their commitments to their employees.

\subsection{Moral legitimacy}

To offer a more genuine form of morality, a leader's authority is explained by a leader's "moral legitimacy" (Baur and Palazzo 2011; Dart 2004; Palazzo and Scherer 2006; Suchman 1995). Moral legitimacy appeals to the "pro-social" or ethical aspects of leadership (Eva et al. 2019; Liden et al. 2014). Unlike pragmatic legitimacy, moral legitimacy deals with an individual's moral virtue or character (Winthrop, 1978) in which moral legitimacy "rests not on judgements about whether a given activity benefits the evaluator, but rather on judgements about whether the 
activity is "the right thing to do"" (Suchman 1995, p. 579). A leader's "rightful" actions are deemed morally legitimate if it involves a commitment to some "altruistic" standard (Suchman 1995, p. 580). This adherence to a moral standard appeals to a "procedural" form of moral legitimacy where moral legitimacy is gained by conforming to or "by embracing socially accepted techniques and procedures" (Suchman 1995, p. 580). Unlike "consequential" forms of moral legitimacy that focus on products or services that produce a moral outcome (i.e. Starbucks free trade coffee, Dolphin Free tuna, Solar panels that reduce carbon footprint), moral (procedural) legitimacy is focused on an individual's conformance to a practice that is desired by society (Baur and Palazzo 2011; Suchman 1995). Such moral (procedural) legitimacy evaluates an individual's legitimacy not on the basis of an individual's ability to affect a morally valuable outcome, but on the basis that the individual conforms to those "socially acceptable techniques and procedures" or "sound practices" (Suchman 1995, p. 580) that promote the attainment of an altruistic social standard.

\subsubsection{Servant leadership}

While an understanding of moral (procedural) legitimacy remains largely confined to institutional research, "servant-leadership" (Greenleaf 1977) offers insights to understanding a leader's moral (procedural) legitimacy. Servant-leadership is particularly relevant to explaining a leader's moral legitimacy because the core task of a servant leader is one of institutional building. Greenleaf (1972) describes: "individuals who want to serve must, on their own, become institution builders where they are." (p.5). Servant leadership involves instituting a type of "sound practice" (Suchman 1995, p. 580) in which the goal of the leader is to empower employees to realize their fullest potential (Eva et al. 2019). This empowerment operates on the basis of a leader's altruistic and ethical orientation (Eva et al. 2019). Unlike other types of leaderships, such as transformational leadership, servant hood is motivated by an "agape love" or "moral love for others" van Dierendonck and Nuijten 2011, p.1244). This love for others involves instituting a commitment to serving others, even if it come at a leader's personal cost. While there are many examples of servant leaders who engage in such institutional building (i.e. Nelson Mandela, Mother Theresa, Martin Luther King, etc.), Jesus fully instituted the practices of a servant leader where he exchanged his life as a ransom for many (New International Version (NIV): Mark 10:43-45). This commitment refers to a central quality of the servantleader where "the great leader is seen as a servant first, and that simple fact is the key to his greatness" (Greenleaf 1977, p.19).

By engaging in a practice of servanthood, servanthood offers a moral (procedural) legitimacy that justifies the "genuine or authentic" aspects of a leader's authority. The "genuine or authentic" aspect of a leader's authority has been attributed to a servant leader's humility (Eva et al. 2019; Sendjaya et al. 2008; van Dierendonck and Nuijten 2011). A leader's servanthood embodies a humility in which a leader's empathy for their employees is not based on advancing the leader's selfinterest. But instead, a leader's humility reflects a "genuine and authentic" commitment to empowering the employees that they serve. This humility promotes an "other than self" orientation where a leader's self-interest becomes sub servient to 
the needs of their employees (Liden et al. 2014; Peterson et al. 2012; Smith et al. 2004). Although the sources of such humility are unclear, a leader's humility in serving others can be explained by an individual's moral virtue (Winthrop 1978). This moral virtue reflects a habitual tendency or personal disposition in which individuals develop their moral character through the practice of doing the right thing (Winthrop 1978 see also MacIntyre 1985). ${ }^{3}$ A leader's humility reflects this disposition in which acts of service to others develop a leader's moral character of loving others with an agape love. This humility offers a moral virtue that is absent in pragmatic explanations because pragmatic explanations offer a morality that is not based on individual's predisposition to doing the right thing. Jesus admonishing of the religious authorities, the Pharisees, offers a useful illustration of these moral distinctions. Jesus charged that the Pharisees' outward acts of religious conformity lacked moral virtue, because these outward expression were done to advance their prestige and status and thus were devoid of any predisposition to serve those in suffering (New International Version (NIV): Mathew 23: 27). In contrast, Jesus' moral virtue is evidenced by his various acts of service in healing the sick and feeding the poor. Such acts reflect a predisposition to loving others and was culminated by his final act to sacrifice himself (New International Version (NIV): Mathew 26: 42) on the cross so that all can have personal relationship with God. Hence, by way of this illustration, servant-leadership's appeal to a leader's humility is important not only because this humility addresses the moral virtue deficiencies of pragmatic legitimacy, but that this humility introduces a more genuine or authentic form of morality to a leader's authority.

A consequence of this moral (procedural) legitimacy is that it offers an authority that reduces a leader's moral opportunism. Moral (procedural) legitimacy creates a normative expectation where a servant-leader prioritizes their commitments to the "follower [employee] first, organizations second, their own last" (Eva et al. 2019; p. 113). With this commitment, a leader's humility develops a normative expectation in which leaders find increasing purpose and meaning in serving others (van Dierendonck 2011). The development of this normative expectation is consistent with servant-hood research that finds servant leaders are institutional builders in which leaders derive their moral legitimacy from attaching increasing meaning and purpose to the service of others (Sendjaya et al. 2008). As a result, although a leader's authority is a source of their moral opportunism, a leader's moral (procedural) legitimacy creates a normative expectation of service that affirms a leader's humility to serving others. This humility opens a leader to the needs of their employees and thus furthers a leader's disposition to serve others in need. As a result, this humility not only increases a leader's moral (procedural) legitimacy, as a servant-leader, but this moral legitimacy (procedural) further reinforces a normative expectation of service

\footnotetext{
3 This follows an Aristotelian view of virtue ethics in which an individual's disposition towards rightful actions requires a habitual reinforcement of those actions that affirm an individual's moral character. In this fashion, a leader's moral virtue is an ongoing volitional process in which individuals over time realize the full potential of their moral character (Winthrop 1978; see also MacIntyre 1985). This Aristotelian view of virtue ethics is consistent with Christian doctrine of Sanctification.
} 
in the leader's authority (vanDuinkerken and Kaspar 2015). A consequence of this social learning process (see also Alvesson and Spicer 2012; Liden et al. 2014) is that a leader's moral (procedural) legitimacy creates a normative expectation of service that reduces a leader's moral opportunism. This is because as a servant leader's moral virtue involves a disposition to doing the right thing, a leader's moral (procedural) legitimacy creates a normative expectation of service that reinforces a leader's moral character (see also MacIntyre $1985^{4}$ ). This reinforcement affirms a leader's humility to serve others to which reduces a leader's self-interest and subsequent moral opportunism.

As a corollary to this reduction of moral opportunism, a leader's moral (procedural) legitimacy offers an authority that promotes employees' trust. Various leadership studies argue and find that servant leaders increase their employees' trust because employees believe that their leaders have altruistic motives in serving others (Eva et al. 2019; Liden et al. 2014; Schwarz et al. 2016; Sendjaya et al. 2008). Namely, employees perceive servant-leaders as stewards in which employees entrust themselves to leaders to empower their lives for the better (Eva et al. 2019). Leadership studies attribute the development of this trust to a social learning explanation (e.g. Liden et al. 2014). For instance, in Liden et al. (2014) study, employees develop a trust in the servant leader because servant leaders inspire employees to emulate and model the behaviors of the servant leader. This emulation "primes" employees' receptivity to a servant leader's behaviors and thus develops employees' trust in a servant leader's actions (Liden et al. 2014; p. 1436). Yet, since a servant leader's moral (procedural) legitimacy reduces a leader's moral opportunism, this reduction of moral opportunism develops an employees' trust in their leader's authority. Specifically, this trust introduces a social learning process (Liu et al. 2012) in which employees' emulation of a servant-leader's humility reinforces a normative expectation of service. As a result of this social learning process, a leader's moral (procedural) legitimacy develops a normative expectation where employees trust the servant-leader because they share a common commitment to serving each other.

\subsubsection{Moral legitimacy and TCE analysis}

A consequence of this moral legitimacy to TCE is that moral legitimacy introduces a normative expectation that leaders in positions of authority cannot be assumed to be morally neutral. Moral legitimacy yields a genuine authority in which a leader's humility introduces a normative expectation that empowering the lives of their employees is the right thing to do. Yet, due to the morally neutral assumption of TCE, this normative expectation of service is not considered in TCE's explanations of authority. This omission ignores a leader's humility or moral virtue in which the

\footnotetext{
4 This institutional process is consistent with MacIntyre's (1985) virtual ethics where he notes, "For the ability of a practice to retain its integrity will depend on the way in which the virtues can be and are exercised in sustaining the institutional forms which are the social bearers of the practice. The integrity of a practice causally requires the exercise of the virtues by at least some of the individuals who embody it in their activities; and conversely the corruption of institutions is always in part at least an effect of the vices." p. 195).
} 
task of a leader's authority is restricted to the morally neutral tasks of monitoring and financially rewarding their employee's productive actions. Yet, leadership studies find that financial incentives contribute to only $15 \%$ of an individual's job satisfaction and that individuals find satisfaction when their jobs provide meaning and purpose (Judge et al. 2010). As moral legitimacy involves instituting a normative expectation of service, this normative expectation empowers employees a greater sense of meaning and purpose in their jobs. This normative expectation can reduce problem of opportunism because individuals -including both the leader and their employees- are empowered to seek their higher aspirational goals and thus are not likely to engage in shirking behaviors. Hence, an important extension to TCE explanations is that a leader's moral legitimacy not only introduces a normative expectation that reduces the moral opportunism in a leader's authority, but that this normative expectation introduces an authority that appeals to an employees' higher calling. In the absence of such normative expectations, TCE's concept of authority will favor a nihilistic view of employees in which employees are to be treated with suspicion and distrust. With this view of authority, leaders can never fully realize their employees' potential (see also Barnard 1938).

\section{Conclusions}

Leadership faces a crisis. An implicit premise of leadership research is that business leaders rely on the power of their authority to influence their employees (Ashford and Sitkin 2019). Yet, as there has been a growing distrust in a leader's authority (Edelman, 2017; Featherston 2019), the task of this study was to develop a conceptual model of leadership in which distrust in a leader's authority is attributed to a concept of "opportunistic authority". Opportunistic authority consists of legal and moral forms of opportunism in which a leader seeks to beguile, cloak and / or deceive employees of their legal and moral responsibilities. This study argues that leaders who engage in pragmatic (influence) and moral (procedural) forms of legitimacy can overcome this opportunism and can increase employees' trust in their authority. Through these developments, this study offers three contributions to organizational governance and leadership research.

First, from the standpoint of governance research, this study's concept of opportunistic authority introduces an aspect of authority that has not been considered in TCE explanations. TCE subscribe to an authority that focusses on the "institutions of governance" (Williamson 1993) where the monitoring and control benefits of hierarchical governance are central to reducing an organization's transaction costs. Yet, Williamson (1993) identifies that there is an "institutional environmental" aspect of authority which is concerned with the "politics, law, the judiciary, norms, customer and the like" (p. 98). Opportunism authority speaks to the institutional environmental aspects of authority in which there are normative expectations placed on a leader's authority. This distinction in authorities is important because the devices used to attenuate opportunism are different. For instance, authority as conceived by TCE, is effective in attenuating hold-up problems with incomplete market exchanges, but TCE cannot deal with the opportunism found within an organization's decision 
hierarchy (e.g. Ghoshal and Moran 1996; Moschandreas 1997). Opportunistic authority deals exclusively with this latter form of opportunism in which the development of normative expectations is key to reducing a leader's legal and moral opportunism. That is, while TCE's concept of authority is a response to solving the problems of external market failure (Coase 1937), the development of normative expectations is a response to an internal market failure where leaders fail to live up to the legal and moral responsibilities of their authority. By accounting for this institutional environmental aspect of authority, this study argues that the transaction cost reducing benefits of authority need to also consider that a leader's failure to live up to the normative expectations of their authority can potentially undermine the institutional efficiencies ascribed by the TCE logic and thus undermine an organization's right to exist (Coase 1937).

Second and relatedly, this study's concept of opportunistic authority introduces a legal and moral opportunism that contributes to the darker or more destructive aspects of leadership research. Leadership studies tend to advocate a positive view of business leadership where the outcomes of leadership involve improvements to an employee's welfare and to an organization's performance (Schyns and Schilling 2013). Yet, a growing body of destructive leadership research has found negative leadership outcomes (Alvesson and Spicer 2012; Bendahan et al. 2015; Conger 1990; Liu et al. 2012; Peterson et al. 2012; Schuh et al. 2013; Schyns and Schilling 2013; Wee et al. 2017). These leadership studies argue that a leader's authority can increase their sense of narcissism and entitlement (e.g. Peterson et al. 2012) in which employees become captive to the power and abuses of their leaders (Bendahan et al. 2015; Peterson et al. 2012; Wee et al. 2017). This study's concepts of legal and moral forms of opportunism reflect such narcistic and self-serving tendencies. Leaders who engage in such opportunism undermines employees' trust in a leader's authority and thus their legitimacy as a leader. This erosion in a leader's trust and legitimacy underlies the crisis faced by leadership today. In that, while a basic task of leadership is to influence employees towards achieving an organization's vision or goal, leaders who engage in legal and moral opportunism will undermine the trust and legitimacy that is necessary to supporting this vision.

Third and as a consequence, this study offers prescriptive or practical implications to solving problems of leadership distrust. Due to a leader's legal and moral opportunism, the development of pragmatic and moral forms of legitimacy is central to overcoming employees' distrust in a leader's authority. The practical implications of this legitimizing view of authority is that leaders who fail to develop pragmatic and moral legitimacy in their authority will invite suspicion by their employees. For instance, a leader who engages in the exclusive monitoring and rewarding of their employees' productive contributions signal a leader's distrust in their employees. This is because such monitoring indicates that employees cannot be trusted to report their own productive contributions and thus employees' actions need to be subject to continued surveillance (Ghoshal and Moran 1996). Clearly, this is not to imply that all employees are to be trusted. But when leaders view their employees in such opportunistic terms, it becomes difficult to develop an employees' trust and commitment to an organization's goals. This study argues that pragmatic (influence) legitimacy can develop an employees' trust in their leader's authority and thus increase 
employees' motivation to perform their assigned activities. The development of such trust can also help reduce problems of opportunism in TCE. Furthermore, according to Barnard's (1938) seminal work on authority, authority resides in an "executive function" where the quintessential task of the leader is to communicate and empower a common purpose to their employees. This study argues that leaders who develop moral (procedural) legitimacy in their authority offers an important means to upholding the moral responsibilities of this executive function. Leaders who fail to uphold this moral responsibility will be viewed as "bosses" or "administrators", rather than leaders who can inspire and motivate (Ashford and Sitkin 2019). As a result, a contribution of this study is that pragmatic (influence) and moral (procedural) legitimacy offer prescriptive implications to overcoming the growing distrust in business leaders by offering employees greater control over their productive performance and a greater freedom to more fully realize their productive potential. More pejoratively speaking, it is the development of this type legitimacy that not only removes a leader's power asymmetry, but as result, can transform an "assh***" boss to one that can be trusted.

With respect to the limitations of this study, the development of measures for this study's proposed arguments are a key challenge. Most notably, both pragmatic and moral legitimacy share a common "taken for grantedness" quality where there is an "absence of questioning" (Deephouse and Suchman 2008; p. 53). This taken for grantedness is difficult to measure because if employees were asked of their perceptions of their leader's pragmatic and moral legitimacy, this assessment is "in itself a form of questioning" (Deephouse and Suchman 2008; p. 54). One potential solution is to assess a leader's pragmatic and moral legitimacy by examining employees' wellbeing. For instance, pragmatic legitimacy can be assessed by the extent to which a leader is willing to conform to the performance standards issued by their employees. This conformance can be measured by the extent to which the leader incorporates their employees' feedback and standards of performance into the leader's decision-making authority (Suchman 1995). With respect to moral legitimacy, a servant leader's empowerment efforts can be measured by administering surveys to employees to assess their level of engagement and self-direction (e.g. van Dierendonck and Nuijten 2011).

It should be noted that while employee surveys can be used to measure a leader's empowerment efforts, it is important to recognize that these empowerment efforts face challenges similar to those challenges found in a leader's pragmatic legitimacy. For instance, like their corporate counterparts, university administrators face increasing pressures to empower their faculty because they are central to achieving their university's higher educational objectives. According to servant leadership research (e.g. Sendjaya et al. 2008; van Dierendonck and Nuijten 2011), an administrator's commitment to serving their faculty can be directly assessed by the extent to which faculty members are empowered by their administrative leaders. In particular, the growth in the use of big data analytics in higher education offers an important strategic tool to realizing an administrator's empowerment efforts because big data analytics can be used to construct surveys to measuring the impact of an administrator's empowerment efforts. However, the challenge with the use of big data analytics is that while they are perceived as ethically neutral, administrators are 
susceptible to a pragmatic legitimacy in which these analytics are used for their personal gain. For instance, according to dark side explanations of leadership (Roberts 2009), administrators can become increasingly focused on measuring the impacts of their empowerment. This is because while measures of empowerment can increase an administrator's moral legitimacy, these measures can also increase an administrator's prestige and standing in the university community (i.e. increasing an administrator's prospects to attaining a higher position in their next appointment). This pragmatic form of empowerment can result in greater demands on faculty to document and report their various productive activities to administrative leaders (i.e. citations, H-index, teaching evaluations, research grants, number of editorial boards). With this greater reporting of data, the empowerment of faculty becomes a means to advancing an administrator's social standing. Hence, while an administrative leader may initially have a genuine commitment to serving faculty, the growth of big data analytics can undermine a leader's moral legitimacy because faculty interests become subservient to a leader's data analytics goals. Such movements toward big data analytics however raise broader concerns to higher education. As universities have become increasingly metric driven, administrative leaders face a normative expectation that scholarly outputs are valued only if they can be readily measured and quantified. Yet, Einstein had once noted, "Not everything that counts can be counted, and not everything that can be counted counts". For instance, faculty who engage in high risk reward research can result in dead-ends that incur opportunity costs to other areas of their research program. Since such negative outcomes do not count, an emphasis towards performance-based outcomes can bias faculty towards avoiding high risk reward programs and thus undermining their full potential. This counting of only positive outcomes in University settings stands in direct contrast to businesses like Amazon and Tesla where failure is "counted" as a fundamental part of the innovation process.

In addition to such measurement considerations, it is also important to highlight some of the boundary conditions surrounding the applicability of this study's arguments. From the standpoint of pragmatic legitimacy, cynics of procedural justice have argued that this type of legitimacy can act as a form of "deceptive control mechanism... masqueraded as corporate responsibility" (Greenwood 2007, p. 320). For instance, in University settings, administrative "leaders" can implement a commitment to procedural justice by encouraging greater faculty governance in university affairs. However, due to their position of authority, administrative leaders can institute policies, "before" faculty are given a chance to discuss the merits of such policies. De Fine Licht et al. (2014) describes this as a "frustration effect" in which sub-ordinates are given limited power to influence the outcomes of decision that have already been made. With respect to moral legitimacy, a commitment to serving others is often viewed as a "public good" and thus is difficult to assign a tangible monetary value. In university settings, senior faculty have "service" responsibilities that involve mentoring junior faculty. However, because servant hood tends to be focused on an empowerment process (e.g. Eva et al. 2019), the value of such mentoring is difficult to measure and evaluate, especially relative to more tangible outcomes, such as teaching and/or research. As a result, a servant leader can face difficulties in instituting moral legitimacy in their authority because they provide a 
service that is not readily "counted" and thus valued by their organization. We argue that the challenges in developing such pragmatic and moral legitimacy in university settings can be important boundary conditions to examining this study's arguments. As a result, an important direction for future research would be to examine the pragmatic and moral legitimizing process in leaders of higher educational institutions as well as leaders in business organization to determine the boundary conditions surrounding the appropriateness of the legitimizing processes in these different institutional settings.

Open Access This article is licensed under a Creative Commons Attribution 4.0 International License, which permits use, sharing, adaptation, distribution and reproduction in any medium or format, as long as you give appropriate credit to the original author(s) and the source, provide a link to the Creative Commons licence, and indicate if changes were made. The images or other third party material in this article are included in the article's Creative Commons licence, unless indicated otherwise in a credit line to the material. If material is not included in the article's Creative Commons licence and your intended use is not permitted by statutory regulation or exceeds the permitted use, you will need to obtain permission directly from the copyright holder. To view a copy of this licence, visit http://creativecommons.org/licen ses/by/4.0/.

\section{References}

Alvesson, M., \& Spicer, A. (2012). Critical leadership studies: the case for critical performativity. Human Relations, 65(3), 367-390.

Argyris, C. (1998). Empowerment: The emperor's new clothes. Harvard Business Review, 76, 98-105.

Ashford, S., \& Sitkin, S. (2019). From problems to progress: a dialogue on prevailing issues in leadership research. The Leadership Quarterly, 30(4), 454-460.

Barnard, C. I. (1938). The Functions of the Executive. Cambridge: Harvard University Press.

Baur, D., \& Palazzo, G. (2011). The moral legitimacy of NGOS as partners of corporations. Business Ethics Quarterly, 21(4), 579-604.

Bendahan, S., Zehnder, C., Pralong, F., \& Antonakis, J. (2015). Leader corruption depends on power and testosterone. Leadership Quarterly, 26(2), 101-122.

Chatterjee, A., \& Hambrick, D. (2007). It's all about me: Narcissistic chief executive officers and their effects on company strategy and performance. Administrative Science Quarterly, 52(3), 351-386.

Chiles, T. H., \& McMackin, J. F. (1996). Integrating variable risk preferences, trust, and transaction cost economics. Academy of Management Review, 21(1), 73-99.

Choudhary, A., Akhtar, S., \& Zaheer, A. (2013). Impact of transformational and servant leadership on organizational performance: a comparative analysis. Journal of Business Ethics, 116(2), 433-440.

Coase, R. H. (1937). The nature of the firm. Economica, 4(16), 386-405.

Comaford, C. (2017). 63\% of employees don't trust their leader -- Here's what you can do to change that. Forbes.com. https://www.forbes.com/sites/christinecomaford/2017/01/28/63-of-employees-donttrust-their-leader-heres-what-you-can-do-to-change-that/\#52f7892e7de4. Accessed 8 Jan. 2020

Conger, J. A. (1990). The dark side of leadership. Organizational Dynamics, 19(2), 44-55.

Dart, R. (2004). The legitimacy of social enterprise. Non-profit management and Leadership, 14(4), 410-424.

Deephouse, D. L., \& Suchman, M. (2008). Legitimacy in organizational institutionalism. In R. Greenwood, C. Oliver, R. Suddaby, \& K. Sahlin-Andersson (Eds.), The Sage handbook of organizational Institutionalism (pp. 49-77). CA, Thousand Oaks: Sage.

De Fine Licht, J., Naurin, D., Esaiasson, P., \& Gilljam, M. (2014). When does transparency generate legitimacy? Experimenting on a context-bound relationship. Governance, 27(1), 111-134.

Dishman, L. (2016). Why employees don't trust their leadership. Fast Company. https://www.fastcompan y.com/3058630/why-employees-dont-trust-their-leadership. Accessed 8 Jan. 2020 
Edelman, D.J. (2017) Trust Barometer Global Report (2017) https://www.slideshare.net/EdelmanInsights /2017-edelman-trust-barometer-global-results-71035413. Accessed 8 Jan. 2020.

Eva, N., Robin, M., Sendjaya, S., Van Dierendonck, D., \& Liden, R. (2019). Servant leadership: a systematic review and call for future research. The Leadership Quarterly, 30(1), 111-132.

Featherston, O. (2019). Why don't people trust business leaders? The CEO Magazine. https://www. theceomagazine.com/business/management-leadership/why-dont-people-trust-business-leaders/. Accessed 12 Jan. 2020.

Ferejohn, J. (1999). Accountability and authority: Toward a theory of political accountability. In A. Pzeworski, S. Stokes, \& B. Manin (Eds.), Democracy, Accountability, and Representation (pp. 131152). Cambridge: Cambridge University Press.

Gambetta, D. (1988). Can we trust? In D. Gambetta (Ed.), Trust: Making and Breaking Cooperative Relations (pp. 213-237). Oxford: Basil Blackwell.

Ghoshal, S., \& Moran, P. (1996). Bad for practice: a critique of the transaction cost theory. Academy of Management Review, 21(1), 13-47.

Greenleaf, R. K. (1972). The Institution as Servant. Cambridge: Center for Applied Studies.

Greenleaf, R. K. (1977). Servant Leadership: A Journey into the Nature of Legitimate Power and Greatness. New York: Paulist Press.

Greenwood, M. (2007). Stakeholder engagement: Beyond the myth of corporate responsibility. Journal of Business Ethics, 74(4), 314-327.

Gustafsson, M. (2004). On Rawls's distinction between perfect and imperfect procedural justice. Philosophy of the Social Sciences, 34(2), 300-305.

Harrison, J. S., Bosse, D. A., \& Phillips, R. A. (2010). Managing for stakeholders, stakeholder utility functions, and competitive advantage. Strategic Management Journal, 31(1), 58-64.

Harvey, M. G., Buckley, M. R., Heames, J. T., Zinko, R., Brouer, R. L., \& Ferris, G. R. (2007). A bully as an archetypal destructive leader. Journal of Leadership and Organization Studies, 14(2), 117-129.

Judge, T. A., Piccolo, R. F., Podsakoff, N. P., Shaw, J. C., \& Rich, B. L. (2010). The relationship between pay and job Satisfaction: A meta-analysis of the literature. Journal of Vocational Behavior, 77, 157-167.

Lea, D. (2004). The imperfect nature of corporate responsibilities to stakeholders. Business Ethics Quarterly, 14(2), 201-217.

Lee, M., \& Koh, J. (2001). Is empowerment really a new concept? The International Journal of Human Resource Management, 12(4), 684-695.

Lee, A., Willis, S. \& Tian, A. (2018). When empowering employees works, and when it doesn't. Harvard Business Review. https://hbr.org/2018/03/when-empowering-employees-works-and-when-it-doesnt. Accessed 15 Jan. 2020.

Liden, R., Wayne, S., Liao, C., \& Meuser, J. (2014). Servant leadership and serving culture: Influence on individual and unit performance. Academy of Management Journal, 57(5), 1434-1452.

Liu, D., Liao, H., \& Loi, R. (2012). The dark side of leadership: A three-level investigation of the cascading effect of abusive supervision on employee creativity. The Academy of Management Journal, 55(5), 1187-1212.

Long, B. S., \& Driscoll, C. (2008). Codes of ethics and the pursuit of organizational legitimacy: theoretical and empirical contributions. Journal of Business Ethics, 77, 173-189.

Lubit, R. (2002). The long-term organizational impact of destructively narcissistic managers. The Academy of Management Executive, 16(1), 127-138.

MacIntyre, A. (1985). After Virtue. London: Cassell.

Monk, A. (2009). Recasting the sovereign wealth fund debate: trust, legitimacy, and governance. New Political Economy, 14(4), 451-468.

Moschandreas, M. (1997). The role of opportunism in transaction cost economics. Journal of Economic Issues, 31(1), 39-58. New International Version. Bible. https://www.biblegateway.com/versions/ New-International-Version-NIV-Bible/

$\mathrm{Ng}$, D. (2019). Should all stakeholders be treated fairly? identifying stakeholders that legitimately matter. Organization Management Journal, 16(4), 298-310.

Palazzo, G., \& Scherer, A. G. (2006). Corporate legitimacy as deliberation: a communicative framework. Journal of Business Ethics, 66(1), 71-88.

Parris, D., \& Peachey, J. (2013). A systematic literature review of servant leadership theory in organizational contexts. Journal of Business Ethics, 113(3), 377-393.

Peterson, S., Galvin, B., \& Lange, D. (2012). CEO servant leadership: exploring executive characteristics and firm performance. Personnel Psychology, 65(3), 565-596. 
Pfeffer, J. (2016). Why the assholes are winning: Money trumps all. Journal of Management Studies, 53(4), 663-669.

Phillips, R. (2003). Stakeholder legitimacy. Journal of Business Ethics, 13(1), 25-41.

Rawls, J. (1971). A Theory of Justice. Cambridge: Harvard University Press.

Roberts, J. (2009). No one is perfect: The limits of transparency and an ethic for 'intelligent' accountability. Accounting, Organizations and Society, 34, 957-970.

Schuh, S., Zhang, X., \& Tian, P. (2013). For the good or the bad? interactive effects of transformational leadership with moral and authoritarian leadership behaviors. Journal of Business Ethics, 116(3), 629-640.

Schwarz, D., Newman, A., Cooper, B., \& Eva, N. (2016). Servant leadership and follower job performance: The mediating effect of public service motivation. Public Administration, 94(4), 1025-1041.

Schyns, B., \& Schilling, J. (2013). How bad are the effects of bad leaders? A meta-analysis of destructive leadership and its outcomes. The Leadership Quarterly, 24(1), 138-158.

Sendjaya, S., Sarros, J. C., \& Santora, J. C. (2008). Defining and measuring servant leadership behavior in organizations. Journal of Management Studies, 45(2), 402-424.

Shellenbarger, S. (2019). Hey, that's my idea! when your boss steals your work. Wall Street Journal. https://www.wsj.com/articles/hey-thats-my-idea-when-your-boss-steals-your-work-1543329410. Accessed Jan 152020.

Smith, B., Montagno, R., \& Kuzmenko, T. (2004). Transformational and servant leadership: content and contextual comparisons. Journal of Leadership \& Organizational Studies, 10(4), 80-91.

Spoelstra, S., Butler, N., \& Delaney, H. (2016). Never let an academic crisis go to waste: leadership studies in the wake of journal retractions. Leadership, 12(4), 383-397.

Suchman, M. C. (1995). Managing legitimacy: Strategic and institutional approaches. Academy of Managerial Review, 20(3), 571-610.

Sutton, , R. I. (2007). The No Asshole Rule: Building a Civilized Workplace and Surviving One That Isn't. Boston: Business Plus.

Taylor, S. M., Tracy, K. B., Renard, M. K., Harrison, K., \& Carroll, S. J. (1995). Due process in performance appraisal: A quasi-experiment in procedural justice. Administrative Science Quarterly, 40(3), 495-523.

Tucker, R., \& Hendrickson, D. (2004). The sources of American legitimacy. Foreign Affairs, 83(6), 18-32.

van Dierendonck, D. (2011). Servant leadership: A review and synthesis. Journal of Management, 37(4), 1228-1261.

van Dierendonck , D., \& Nuijten, I. (2011). The servant leadership survey: development and validation of a multidimensional measure. Journal of Business Psychology, 26, 249-267.

vanDuinkerken, W., \& Kaspar, W. (2015). Leading libraries: how to create a service culture. Chicago: ALA Editions.

Vrendenburgh, D., \& Brender, Y. (1998). The hierarchical abuse of power in work organizations. Journal of Business Ethics., 17, 1337-1347.

Warren, R. C. (2003). The evolution of business legitimacy. European Business Review, 15(3), $153-163$.

Wee, E. X. M., Liao, H., Liu, D., \& Liu, J. (2017). Moving from abuse to reconciliation: A powerdependence perspective on when and how a follower can break the spiral of abuse. Academy of Management Journal, 60(6), 2352-2380.

Williamson, O. E. (1975). Markets and Hierarchies. New York: Free Press.

Williamson, O. E. (1993). Transaction cost economics and organization theory. Oxford University Press, 2(2), 107-156.

Winthrop, D. (1978). Aristotle and theories of justice. The American Political Science Review, 72(4), 1201-1216.

Wisner, M. (2016). Disney workers forced to train their foreign replacements. Fox Business. https://www. foxbusiness.com/features/disney-workers-forced-to-train-their-foreign-replacements. Accessed 12 Jan. 2020 .

Zehnder, C., Herz, H., \& Bonardi, J. (2017). A productive clash of cultures: injecting economics into leadership research. The Leadership Quarterly, 28(1), 65-85.

Publisher's Note Springer Nature remains neutral with regard to jurisdictional claims in published maps and institutional affiliations. 